\title{
PEMIKIRAN MUHAMMAD SHAHRUR TENTANG RELASI FILSAFAT BAHASA DAN MODERNITAS
}

\author{
Muhammad In'am Esha
}

\begin{tabular}{c} 
Email: muhammadinamesha@gmail.com \\
$\begin{array}{c}\text { Fakultas Humaniora dan Budaya, Universitas Islam Negeri Maulana Malik Ibrahim Malang } \\
\text { Alamat Koresponden: Jalan Gajayana 50 Malang 65144 }\end{array}$ \\
\hline
\end{tabular}

\begin{abstract}
Study on philosophy of language, especially on contemporary Islamic thinker, is very needed for enriching thinking spectrum on this object. We hope this paper can open our horizon on this topics and enhance our knowledge especially on philosophy of language in Islamic perspective. This paper affords to describe Shahrur's thought on relation between philosophy of language and modernity. Important findings of the paper are: first, language as important reality in human life. With language realities of human life can be articulated well. So, language is a mirror of reality. Second, when we understand that "language as mirror of reality", actually we make language passively. Shahrur's philosophical thought on language gives us understanding that language can be functioned as active tool for developing progressive ethos and value for supporting modernity in Islamic world. Third, Philosophy of language gives us possibility for raising a new horizon of understanding on language as object of study.
\end{abstract}

\section{Keywords}

Shahrur, Filsafat Bahasa, Modernitas

\section{Pendahuluan}

Apa hubungan filsafat bahasa dan modernitas? Kiranya pertanyaan tersebut muncul tatkala membaca judul tulisan ini. Oleh karena itu, sebelum dibahas beberapa hal terkait ada baiknya dipaparkan terlebih dahulu pokok-pokok pikiran yang menjadi dasar pijakan dalam tulisan ini.

Pertama, bahwa tatkala kita membincang tentang filsafat bahasa sebenarnya kita tidak sedang membahas tentang "hal kebahasaan", tetapi lebih pada sesuatu yang "melampaui" bahasa. Hal ini yang menjadi ciri dari model berpikir filsafat. Filsafat tidak sekadar membahas tentang apa yang "tampak", tetapi lebih dari itu ia membahas tentang sesuatu yang berada dibalik yang tampak itu. Itulah sebabnya, Musa Asy'ari misalnya, menyatakan bahwa filsafat mengajak orang untuk berpikir pada dataran makna (Asy'ari, 2000). Tatkala kita melihat manusia, filsafat tidak sekadar membahas tentang "apanya" manusia, tetapi lebih dari itu filsafat membahas tentang apa makna "adanya" manusia di muka bumi ini.

Kedua, bahwa bahasa pada hakikatnya merupakan simbol yang digunakan manusia terhadap realitas empiris. Tatkala kita melihat realitas berupa "lembaran-lembaran kertas yang berisi tulisan dan dijilid", dengan menggunakan simbol-simbol huruf kita menamakannya dengan buku (Indonesia), book (Inggris), kitabun (Arab), atau sastra (Jawa Kuno). Bahasalah yang membuat kehidupan kita menjadi mudah dan sederhana karena pemakaian simbol-simbol kebahasaan tadi. Betapa susahnya manusia tatkala harus mengatakan misalnya: "Saya tadi baru membeli lembaran-lembaran kertas yang berisi tulisan sejarah dan dijilid karya Pak In'am". Padahal kata-kata tadi bisa disampaikan dengan sederhana: "Saya tadi baru membeli buku sejarah karya Pak In'am". Tidak mengherankan jika kita bisa mengatakan bahwa dalam hasanah filsafat kebahasaan tatkala kita membahas filsafat bahasa sebenarnya merupakan abstraksi pada level kedua atau kalau meminjam bahasa Alvesson and Skoldberg (2000) disebut diadri hermeneutic.

Fokus tulisan ini bertujuan untuk mendeskripsikan tinjauan filosofis tentang asal kata (mustaq) dalam bahasa Arab. Seperti yang lazim dipaparkan dalam kajian bahasa Arab bahwa asal muasal kata dalam bahasa Arab selama ini dikenal dua pendapat. Kelompok pertama yang berpendapat bahwa asal muasal kata adalah fiil madli, sedangkan kelompok kedua berpendapat bahwa mashdar-lah sebagai mustaq sebuah dalam bahasa Arab. 
Di era kontemporer ini, adalah seorang pemikir dari Syiria Muhammad Shahrur, yang berpendapat bahwa asal mula kata bukanlah berasal dari fiil madli maupun mashdar. Ia berpendapat bahwa asal muasal kata berasal dari fiil amr. Mengapa ia berpendapat demikian? Hal inilah yang ingin dikaji dalam tulisan ini.

Secara teoretik, tulisan ini menggunakan kerangka berpikir sebagaimana yang ada dalam filsafat bahasa. Kaelan (1998: 5) dalam Filsafat Bahasa dijelaskan bahwa setidaknya ada dua perhatian: pertama, perhatian filsuf terhadap bahasa dalam menganalisis, memecahkan, dan menjelaskan problem-problem dan konsep-konsep filosofis; kedua, perhatian filsuf terhadap bahasa sebagai objek materi yaitu membahas dan mencari hakikat bahasa yang pada gilirannya memunculkan aliranaliran dalam teori kebahasaan. Hal ini berarti, kalau yang pertama menjadikan bahasa sebagai sarana analisis dalam memecahkan persoalan, sedangkan yang kedua menjadikan bahasa sebagai objek kajian dalam filsafat. 


\section{Penutup}

Uraian di atas memberikan beberapa penjelasan tentang relasi filsafat bahasa dan modernitas. Setidaknya terdapat beberapa hal yang dapat kita simpulkan:

Pertama, bahasa sebagai realitas sejati manusia tidak dapat dilepaskan dari eksistensi atau keberadaan manusia di dunia. Dalam segala aktivitasnya, manusia tidak dapat dilepaskan dari bahasa. dalam bersosial, berbudaya, dan berpolitik manusia memerlukan bahasa. Tidak mengherankan jika para ahli mengatakan bahwa bahasa adalah cermin realitas manusia.

Kedua, sebagai hal yang sangat lekat dengan kehidupan manusia, bahasa senantiasa dikaji secara terus-menerus. Filsafat bahasa yang mengkaji persoalan bahasa dalam perspektif filosofis memberikan ruang pemaknaan yang memungkinkan manusia menemukan pemikiranpemikiran baru seiring dengan perkembangan dan kebutuhan zamannya. Termasuk dalam hal ini pemikiran pembaruan yang coba digagas oleh para pemikiran Muslim kontemporer.

Kedua, pemikiran Shahrur memberikan pemahaman bahwa kalau selama ini bahasa biasa dipandang sebagai cermin realitas sosial, budaya, dan politik atau biasa istilahkan dengan language as mirror of realities, maka dalam pandangan ini bahasa tidak lebih sebagai sebuah "benda mati", sebuah cermin, yang pasif dan hanya bertugas untuk memantulkan atau merefleksikan realitas. Tetapi, dalam pemikiran Shahrur kita bisa cermati bahwa melalui pemikiran filosofis terhadap fenomena kebahasaan, bahasa bisa difungsikan sebagai daya pengubah terhadap ketidaksadaran publik yang kurang mendukung upaya pembaruan dan modernisasi. Bahasa disini difungsikan sebagai peranti aktif dalam menumbuhkan elan progresifisme di dalam masyarakat. Melalui pemikirannya bahwa mustaq-nya kalimat dalam bahasa Arab adalah fi'il amr, misalnya, ia ingin menjadikan bahasa sebagai pembentuk etos progresif di kalangan umat menuju masyarakat yang modern.

Ketiga, sebagai hal yang sangat lekat dengan kehidupan manusia, bahasa senantiasa dikaji secara terus-menerus. Filsafat bahasa yang mengkaji persoalan bahasa dalam perspektif filosofis memberikan ruang pemaknaan yang memungkinkan manusia menemukan pemikiranpemikiran baru seiring dengan perkembangan dan kebutuhan zamannya. Termasuk dalam hal ini pemikiran pembaruan yang coba digagas oleh para pemikiran muslim kontemporer.

\section{DAFTAR PUSTAKA}

Al-Jabiri, M. Abed. 1991. Al-Turast wa al-Hadastah: Dirasah wa Munaqasah. Beirut: Markaz Al-Tsaqafiy AlArabi,

Al-Jabiri, M. Abed. 2000. Post Tradisionalisme Islam. Terjemahan: Ahmad Baso. Yogyakarta: LKiS

Al-Syawwaf, Mahammi Munir Muhammad Thahir. 1993. Tahafut al-Qira'ah al-Mu'ashirah, Cyprus: Al-Nasyr.

Assyaukanie, A. Luthfie. 1998. Tipologi dan Wacana Pemikiran Arab Kontemporer. Jurnal Paramadina Vol. 1 No. 1. Juli-Desember.

Asy’arie, Musa. 1999. Filsafat Islam: Sunnah Nabi dalam Berpikir. Yogyakarta: LESFI.

Commins, David. 1986. Religius Reformers and Arabists in Damaskus, 1885-1914. International Jurnal of Midle East Studies, 18.

Eickelman, Dale F. 1993. Islamic Liberalism Strikes Back. Midle East Studies Association (MESA) Bulletin 27, 1, Desember.

Eickelman, Dale F. 1998. The Inside Islamic Reformation. The Wilson Quarterly, 22, No. 1. Winter.

Ensiklopedia Indonesia. Edisi Khusus. Jakarta: PT Ichtiar Baru - Van Hoeve.

Esposito, John L. (Ed.). 1995. The Oxford Encyclopedia of The Modern Islamic World. Vol. IV. New York: Oxford University Press. 
Hanafi, Hasan, dan Muhammad Abid al-Jabiri. 2003. Membunuh Setan Dunia Meleburkan Timur dan Barat dalam Cakrawala Kritik dan Dialog. Terjamahan Umar Bukhori. Yogyakarta: IRCiSoD.

Hanafi, Hasan. 2000. Oksidentalisme, Sikap Kita Terhadap Barat, (trj.) M.Najib Buchori, Jakarta: Paramadina.

Hardiman, F. Budi. 2003. Melampaui Positivisme dan Modernitas, Yogyakarta: Kanisius.

Kurzman, Charles. (Ed.). 1998. Liberal Islam, A Sourcebook, New York-Oxford: Oxford University Press.

Madjid, Nurcholis. 1998. "Islam dan Politik". Jurnal Pemikiran Islam Paramadina, Volume I Nomor I. Jakarta: Paramadina.

Magnis-Suseno, Franz. 1990. Filsafat Sebagai Ilmu Kritis, Yogyakarta: Kanisius.

Magnis-Suseno, Franz. 1999. Pemikiran Karl Marx, Jakarta: Gramedia.

Misbah, Yazdi, Taqi. 2003. Buku Daras Filsafat Islam, Bandung: Mizan.

Nasr, Sayyed Husein. 2003. Ensiklopedi Tematis Filsafat Islam. Bandung: Mizan.

Putro, Suadi. 1998. Islam dan Modernitas Menurut Arkoun. Jakarta: Paramadina.

Rahardjo, Mudjia. 2007. Hermeneutika Gadamer: Kuasa Bahasa dalam Wacana Politik Gus Dur. Malang: UIN Malang Press.

Rappar, J. Hendrik. 1996. Pengantar Filsafat. Yogyakarta: Kanisius.

Schulza, Reinhard. 2000. A Modern History of The Islamic World. London: IB. Tauris.

Shahrur, Muhammad. 1990. Al Kitab Wa Al Qur'an: Qira'ah Mu'ashirah, Demaskus: Al-Ahaliy Al- Thiba'ah wa Al-Nasyr wa Al-Tauzi'.

Shahrur, Muhammad. Teks Ketuhanan dan Pluralisme pada Masyarakat Muslim, (terj.) M. Zaki Hussein, dalam http://IslamPembebasan.Virtualave.net

Widodo, Amd, dkk. 2001. Kamus Ilmiah Populer. Yogyakarta: Absolut.

Yatim, Badri. 2001. Sejarah Peradaban Islam. Jakarta: PT RajaGrafindo Persada. 